\title{
A systematic review of controlled clinical trials on the prevention of back pain in industry
}

\author{
Mireille N M van Poppel, Bart W Koes, Tjabe Smid, Lex M Bouter
}

\begin{abstract}
Objective-To assess the effectiveness of lumbar supports, education, and exercise in the prevention of back pain in industry. Methods-A computerised search for controlled clinical trials was conducted. A criteria list was used to assess the methodological quality of the studies. The available evidence for the effectiveness of the interventions was graded with a rating system for the level of evidence. Effect sizes of individual studies were combined if the studies were sufficiently similar.

Results-11 studies were identified for the review. The methodological quality of all studies was low, with a maximum score of three out of seven for internal validity. There was no evidence for the effectiveness of lumbar supports due to contradictory outcomes of the studies. Five of the six studies on education reported no effect. Thus there is limited evidence that education does not help to prevent back pain. All three studies on exercise reported a positive result, indicating limited evidence for the effectiveness of exercise. The combined effect size for exercise was 0.53 , which is a medium sized effect.

Conclusions-Although widely used, there is little evaluative research on the preventive measures studied here. The review showed that there is limited evidence that exercise has some effect in the prevention of back pain and that education is not effective. No conclusive evidence was found for or against the effectiveness of lumbar supports. Research of higher methodological quality is needed before firm conclusions on the effectiveness of lumbar supports, education, and exercise in the prevention of back pain in industry can be drawn.
\end{abstract}

Keywords: back pain; prevention; review

Back pain is one of the most common complaints in industrial countries. Lifetime prevalences have been reported to be as high as $60 \%-90 \%$. ${ }^{1}$ Furthermore, it is one of the most expensive disorders to society: the total direct medical costs due to back pain in The Netherlands in 1991 were estimated at US $\$ 367.6$ million, and the total costs for absenteeism and disability payments at US $\$ 3.1$ billion and US $\$ 1.5$ billion, respectively. ${ }^{2}$
Working conditions are often presumed to play an important part in the aetiology of back pain. As a consequence, prevention programmes are introduced by industrial employers in an attempt to reduce the incidence of back pain, and its associated sick leave and compensation costs. Besides ergonomic adjustments of the workplace, these programmes most often consist of either lumbar supports, education, lifting instructions, exercise, or combinations of these.

Although these interventions may be effective in the reduction of certain risk factors, the effectiveness of the interventions in the prevention of back pain at the workplace is still under debate. Previous reviews on lumbar supports ${ }^{3-6}$ and education ${ }^{4}$ reported that the effectiveness of these interventions in the prevention of back pain had not yet been demonstrated in clinical trials. None of these reviews were restricted to controlled clinical trials and thus included potentially severely biased studies. Furthermore, none of the reviews assessed the methodological quality of the studies on which they based their conclusions, nor did they state explicitly on what criteria their conclusions were based.

In this article we try to evaluate the evidence for the effectiveness of education, exercise, and lumbar supports in the prevention of back pain in industry in a systematic way, by assessing the methodological quality of the studies, and by grading the level of evidence with a rating system. The methodological quality, the outcome, and the number of studies were taken into account in the rating system.

\section{Methods}

SELECTION OF PAPERS

We conducted a MEDLINE (1966-96), ERIC (1966-96), EMBASE (1988-96), and Psychlit (1984-96) search of papers using the following keywords: back pain, backache, musculoskeletal diseases, orthoses, exercise, education, prevention, and controlled trial. No language restriction was used. References in relevant publications were examined for additional studies. Abstracts and unpublished material were not included. To be included in this review papers had to meet the following criteria: (a) controlled clinical trial (CCT): a prospective design in which an intervention group is compared with a concurrent control group which is derived from the same setting as the intervention group, and with randomised or non-randomised allocation of subjects to the study groups, (b) intervention aimed at the 
Table 1 Criteria list for the methodological assessment of controlled clinical trials on the prevention of back pain

Criteria

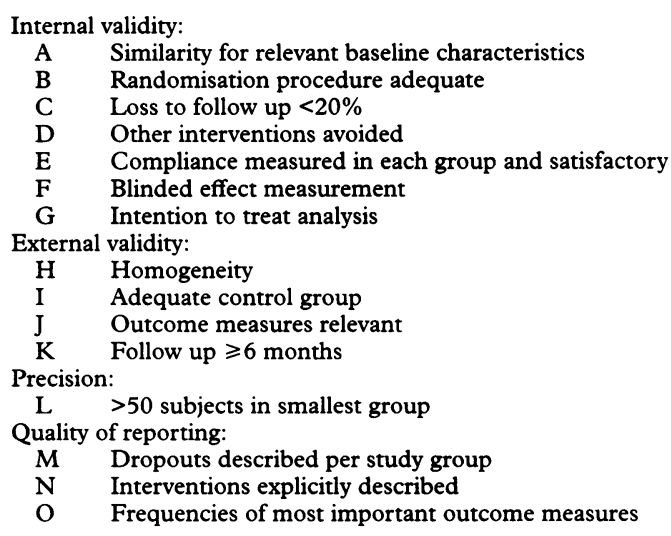

prevention of back pain, consisting of education, exercise, or wearing a lumbar support, (c) no restriction to subjects with back pain at the start of the study, (d) intervention in an industrial setting.

ASSESSMENT OF METHODOLOGICAL QUALITY All trials were scored according to the methodological criteria (table 1, appendix). These criteria are based on generally accepted principles of intervention research. Similar criteria have been used in previous reviews about therapeutic interventions for low back pain..$^{8-10}$ The methodological quality of the studies was assessed by two reviewers independently (BK, $\mathrm{MP}$ ). The assessments resulted in a hierarchical list based on the number of internal validity items scored positive.

LEVELS OF EVIDENCE

Conclusions on the efficacy of a preventive intervention were based on the strength of the available evidence. The strength of the evidence was determined according to a rating system $^{11}$ which was based on the United States clinical practice guideline for acute low back problems in adults. ${ }^{12}$ This rating system consisted of four levels of evidence based on the number, the methodological quality, and the outcome of the studies at issue.

- Level 1: strong evidence-multiple relevant, high quality randomised clinical trials (RCTs) with consistent outcomes

- Level 2: moderate evidence-one relevant, high quality RCT and one or more relevant low quality RCTs or non-randomised controlled clinical trials (CCTs) (high or low quality). Consistent outcomes of the studies

- Level 3: limited evidence-only one high quality RCT or multiple low quality RCTs and non-randomised CCTs (high or low quality). Consistent outcomes of the studies

- Level 4: no evidence - only one low quality RCT or one non-randomised CCT (high or low quality), no relevant studies, or contradictory outcomes of the studies

The outcomes of the studies were considered to be contradictory if $<75 \%$ of the studies reported the same outcome, otherwise out- comes were considered to be consistent. Studies were rated to be relevant if at least one of the following outcome measures was used: the incidence of back pain, the number of subjects, days, episodes with back pain, or sick leave. A study was considered to be of high quality if the study scored positive on at least four of the seven items on internal validity $(>50 \%)$, otherwise it was considered to be of low methodological quality.

\section{DATA EXTRACTION AND ANALYSIS}

To be able to combine the outcomes of different studies statistically, data were extracted from each study. The following data were of interest: the number of subjects in each study group, means (SDs) of data on sick leave, and incidence of back pain at follow up. This could be directly after the intervention period or after an additional follow up period.

It was expected that different outcome measures would be used in the different studies and that the outcome measures would be in the form of continuous data-for example, number of days lost from work, number of days or episodes with back pain. Therefore, we chose the "effect size", and more particularly the Cohen's $d^{13}$ as the method for estimating the combined effect. The Cohen's $d$ is the difference between the means of the outcome measure in two intervention groups divided by the pooled SD of the means. The effect size consequently expresses the magnitude of an effect as the number of pooled SDs. Effect sizes were calculated with data from the intervention group and the control group from the latest measurement after follow up. No differences before and after were used to calculate effect sizes. If the occupation of the study population, the intervention, and the outcome measure were reasonably similar, according to the reviewers, the combined effect size was calculated. ${ }^{13}$ The fixed effects model was used if homogeneity of the study effect sizes was not rejected. Otherwise, the random effects model was used. Studies were weighted by their variance in effect size.

\section{Results}

Eleven studies (seven RCTs and four nonrandomised CCTs) that met our selection criteria were identified. ${ }^{14-24}$ There was initial disagreement on $68(21 \%)$ of 319 items scored to determine the methodological quality of the studies. Disagreement was mostly due to reading and interpretation errors, and was solved in a single consensus meeting. Table 2 lists the studies in a hierarchical order, according to their internal validity score. The RCTs scored from zero to three positive items out of the seven items for internal validity, and the nonrandomised CCTs from zero to two. This indicated poor overall methodological quality of the studies. The most prevalent shortcomings were (D) no measures taken to avoid cointerventions and $(F)$ no blinded outcome assessment.

\section{LUMBAR SUPPORTS}

We identified five studies evaluating the effectiveness of lumbar supports: three 
Table 2 Methodological quality of controlled clinical trials on the effectiveness of interventions in the prevention of back pain

\begin{tabular}{|c|c|c|c|c|c|c|c|c|c|c|c|c|c|c|c|c|}
\hline \multirow[b]{2}{*}{ Authors } & \multicolumn{8}{|c|}{ Internal validity } & \multicolumn{8}{|c|}{ External validity/precision/quality of reporting } \\
\hline & $A$ & $B$ & $C$ & $D$ & E & $F$ & $G$ & $\begin{array}{l}\text { Validity } \\
\text { score }\end{array}$ & $H$ & $I$ & $\boldsymbol{F}$ & $K$ & $L$ & $M$ & $N$ & $O$ \\
\hline \multicolumn{17}{|l|}{$\begin{array}{l}\text { RCTs: } \\
\text { Lumbar support: }\end{array}$} \\
\hline $\begin{array}{l}\text { Lumbar support: } \\
\text { Walsh and } \\
\text { S }\end{array}$ & - & + & + & - & - & - & + & 3 & + & + & - & + & - & - & - & + \\
\hline Alexander et al ${ }^{16}$ & - & - & + & - & - & - & + & 2 & - & + & - & - & - & + & - & + \\
\hline Reddell $e t a l^{15}$ & - & - & - & - & - & - & - & 0 & - & + & - & + & + & - & + & - \\
\hline Education: & & & & & & & & & & & & & & & & \\
\hline $\begin{array}{l}\text { Walsh and } \\
\text { Schwartz }\end{array}$ & - & + & + & - & - & - & + & 3 & + & + & - & + & - & - & - & + \\
\hline Donchin et $a^{19}$ & - & - & + & - & - & - & + & 2 & - & + & - & + & - & - & - & - \\
\hline Daltroy $e t a l^{0}$ & + & - & - & - & - & - & - & 1 & - & + & - & + & + & - & + & - \\
\hline \multirow{2}{*}{\multicolumn{17}{|c|}{ Exercises: }} \\
\hline & & & & & & & & & & & & & & & & \\
\hline Gundewall et a $P^{3}$ & + & - & + & - & - & - & - & 2 & - & + & - & + & - & - & + & + \\
\hline Donchin et al ${ }^{19}$ & - & - & + & - & - & - & + & 2 & - & + & - & + & - & - & - & - \\
\hline \multirow{3}{*}{\multicolumn{17}{|c|}{ Non-randomised CCTs: }} \\
\hline & & & & & & & & & & & & & & & & \\
\hline & - & & & & & & & & & & & & & & & \\
\hline Anderson et al $\mathrm{l}^{17}$ & - & $\overline{-}$ & $\stackrel{+}{-}$ & $\overline{-}$ & $\overline{+}$ & $\overline{-}$ & $\begin{array}{l}+ \\
-\end{array}$ & $\begin{array}{l}2 \\
1\end{array}$ & $\overline{-}$ & $\overline{+}$ & $\overline{-}$ & $\bar{t}$ & $\bar{z}$ & $\begin{array}{l}+ \\
-\end{array}$ & $\begin{array}{l}+ \\
+\end{array}$ & $\begin{array}{l}- \\
-\end{array}$ \\
\hline Education: & & & & & & & & & & & & & & & & \\
\hline Versloot $e t$ a $P^{1}$ & - & - & + & - & - & - & - & 1 & - & + & - & + & + & - & + & + \\
\hline Feldstein $e t a l^{2}$ & - & - & - & - & - & - & - & 0 & - & + & - & - & - & - & - & - \\
\hline
\end{tabular}

RCTs, ${ }^{14-16}$ and two non-randomised CCTs (table 3). ${ }^{17} 18$

Compliance with wearing the lumbar support was reported in two studies only. In the study of Anderson et al $^{17}$ compliance was over $80 \%$, according to the supervisors at the work site. In the study of Reddell $e t$ al $^{15} 42 \%$ of the subjects used the lumbar support during the complete intervention period.

Only one of the three low quality RCTs reported a positive effect of wearing a lumbar support (in combination with education). The other two RCTs reported no effect of lumbar supports and both non-randomised CCTs did show a positive effect of lumbar supports. After applying the rating system for the level of evidence, the results indicate that there is no evidence for or against the effect of lumbar supports at this moment (level 4), due to the contradictory outcomes of the studies $(60 \%$ of the studies positive, $40 \%$ no effect).

\section{EDUCATION}

Table 4 lists the six studies on the effectiveness of education or back schools for the prevention of back pain that were identified: four RCTs, ${ }^{14151920}$ and two non-randomised CCTs. ${ }^{212}$

Table 3 Controlled clinical trials on the effectiveness of lumbar supports in the prevention of back pain in industry

\begin{tabular}{|c|c|c|c|c|c|c|}
\hline Authors & Subjects & Interventions & Subjects (n) & $\begin{array}{l}\text { Follow up } \\
\text { period } \\
\text { (months) }\end{array}$ & $\begin{array}{l}\text { Validity } \\
\text { score }\end{array}$ & Main result (according to authors) \\
\hline $\begin{array}{l}\text { RCTs: } \\
\text { Walsh and } \\
\text { Schwartz }\end{array}$ & $\begin{array}{l}\text { Warehouse } \\
\text { workers }\end{array}$ & $\begin{array}{l}\text { (1) } 1 \mathrm{~h} \text { training on back pain } \\
\text { prevention and body mechanics, and } \\
\text { lumbar support } \\
\text { (2) } 1 \mathrm{~h} \text { training on back pain } \\
\text { prevention } \\
\text { (3) Control }\end{array}$ & $\begin{array}{l}27 \\
27 \\
27\end{array}$ & 6 & 3 & $\begin{array}{l}\text { No differences in back injury } \\
\text { incidence between groups (no data), } \\
\text { but change in pre-post-training } \\
\text { difference in mean days lost from } \\
\text { work in group } 1 \text { compared with group } \\
3 \text {. Group } 2 \text { no significant change: (1) } \\
-2.5 \text { (2) }-0.6 \text { (3) } 0.4\end{array}$ \\
\hline Alexander $e t a l^{16}$ & $\begin{array}{l}\text { Healthcare } \\
\text { workers }\end{array}$ & $\begin{array}{l}\text { (1) Lumbar support } \\
\text { (2) Control }\end{array}$ & $\begin{array}{l}30 \\
30\end{array}$ & 3 & 2 & $\begin{array}{l}\text { No differences after } 3 \text { months in } \\
\text { number of self reported back injuries } \\
\text { between groups: (1) } 1 \text { (2) } 2\end{array}$ \\
\hline Reddell et al ${ }^{15}$ & $\begin{array}{l}\text { Airline baggage } \\
\text { handlers }\end{array}$ & $\begin{array}{l}\text { (1) Lumbar support } \\
\text { (2) } 1 \mathrm{~h} \text { training session on spine } \\
\text { anatomy and body mechanics } \\
\text { (3) } 1 \mathrm{~h} \text { training session and lumbar } \\
\text { support } \\
\text { (4) Control }\end{array}$ & $\begin{array}{l}145 \\
122 \\
127 \\
248\end{array}$ & 8 & 0 & $\begin{array}{l}\text { No differences in back injury } \\
\text { incidence rate, lost work days, or } \\
\text { compensation rate between groups } \\
\text { after } 8 \text { months (no data) }\end{array}$ \\
\hline $\begin{array}{l}\text { Non-randomised } \\
\text { CCTs: } \\
\text { Thompson et al }{ }^{18}\end{array}$ & Hospital workers & $\begin{array}{l}\text { (1) Lumbar support, back school ( } 8 \mathrm{~h} \\
\text { in } 2-3 \text { sessions) and instructions on } \\
\text { warm up exercises } \\
\text { (2) Back school ( } 8 \mathrm{~h} \text { in } 2-3 \text { sessions) } \\
\text { and instructions on warm up } \\
\text { exercises }\end{array}$ & $\begin{array}{l}41 \\
19\end{array}$ & 3 & 2 & $\begin{array}{l}\text { Lumbar support use associated with } \\
\text { decreased experience of back pain in } \\
\text { logistic regression analysis after } 3 \\
\text { months (no data) }\end{array}$ \\
\hline Anderson $e t a l^{17}$ & $\begin{array}{l}\text { Warehouse } \\
\text { workers }\end{array}$ & $\begin{array}{l}\text { (1) Lumbar support } \\
\text { (2) Control }\end{array}$ & $\begin{array}{l}1 \text { work site } \\
2 \text { work sites } \\
\text { (Total: } 266 \text { ) }\end{array}$ & 12 & 1 & $\begin{array}{l}\text { Reduction in injury rate (number of } \\
\text { injuries } / 200000 \mathrm{~h} \text { worked) after } 12 \\
\text { months in group } 1(26.2) \text { compared } \\
\text { with group } 2(39.0 \text { and } 29.4)\end{array}$ \\
\hline
\end{tabular}


Table 4 Controlled clinical trials on the effectiveness of education or a back school programme in the prevention of back pain in industry

\begin{tabular}{|c|c|c|c|c|c|c|}
\hline Authors & Subjects & Interventions & $\begin{array}{l}\text { Subjects } \\
(n)\end{array}$ & $\begin{array}{l}\text { Follow up } \\
\text { period } \\
\text { (months) }\end{array}$ & $\begin{array}{l}\text { Validity } \\
\text { score }\end{array}$ & Main result (according to authors) \\
\hline $\begin{array}{l}\text { RCTs: } \\
\text { Walsh and } \\
\text { Schwartz }{ }^{14}\end{array}$ & $\begin{array}{l}\text { Warehouse } \\
\text { workers }\end{array}$ & $\begin{array}{l}\text { (1) } 1 \mathrm{~h} \text { training on back pain prevention, } \\
\text { body mechanics, and lumbar support } \\
\text { (2) } 1 \mathrm{~h} \text { training on back pain prevention } \\
\text { (3) Control }\end{array}$ & $\begin{array}{l}27 \\
27 \\
27\end{array}$ & 6 & 3 & $\begin{array}{l}\text { No differences in back injury } \\
\text { incidence between groups (no data), } \\
\text { but change in pre-post-training } \\
\text { difference in mean days lost from } \\
\text { work in group } 1 \text { compared with group } \\
3 \text {. Group } 2 \text { no significant change: (1) } \\
-2.5 \text { (2) }-0.6 \text { (3) } 0.4\end{array}$ \\
\hline Donchin et $a l^{19}$ & Hospital workers & $\begin{array}{l}\text { (1) Calisthenic exercises for back and } \\
\text { abdominal muscles. } 45 \text { min biweekly } \\
\text { (2) Instructions on body mechanics and on } \\
\text { exercises for abdominal and back muscles. } \\
\text { Four sessions of } 90 \text { min in } 2 \text { weeks plus fifth } \\
\text { session after } 2 \text { months } \\
\text { (3) Control }\end{array}$ & $\begin{array}{l}46 \\
46\end{array}$ & 12 & 2 & $\begin{array}{l}\text { Reduction in incidence of low back } \\
\text { pain episodes (number of painful } \\
\text { months) after } 12 \text { months in group } 1 \\
\text { (4.5) compared with group } 2(7.3) \text { or } \\
\text { group } 3(7.4) \text {. No difference in back } \\
\text { pain incidence between group } 2 \text { and } \\
\text { group } 3 \text {. }\end{array}$ \\
\hline Reddell et $a^{15}$ & $\begin{array}{l}\text { Airline baggage } \\
\text { handlers }\end{array}$ & $\begin{array}{l}\text { (1) Lumbar support } \\
\text { (2) } 1 \mathrm{~h} \text { training session on spine anatomy } \\
\text { and body mechanics } \\
\text { (3) } 1 \mathrm{~h} \text { training session and lumbar support } \\
\text { (4) Control }\end{array}$ & $\begin{array}{l}145 \\
122 \\
127 \\
248\end{array}$ & 8 & 0 & $\begin{array}{l}\text { No differences in back injury } \\
\text { incidence rate, lost work days or } \\
\text { compensation rate between groups } \\
\text { after } 8 \text { months (no data) }\end{array}$ \\
\hline $\begin{array}{l}\text { Non-randomised } \\
\text { CCTs: } \\
\text { Versloot } e t a l^{1}\end{array}$ & Bus drivers & $\begin{array}{l}\text { (1) Information on health, stress, coping } \\
\text { strategies, and relaxation exercises. Three } \\
\text { sessions with } 6 \text { month intervals } \\
\text { (2) Control }\end{array}$ & 200 & 24 & 1 & $\begin{array}{l}\text { Reduction in mean duration of } \\
\text { absenteeism (days) in group } 1 \text { (49.3) } \\
\text { compared with group } 2 \text { (59.9) after } 48 \\
\text { months follow up }\end{array}$ \\
\hline Feldstein $e t a l^{2}$ & Hospital workers & $\begin{array}{l}\text { (1) } 2 \mathrm{~h} \text { session on body mechanics and } \\
\text { lifting techniques plus } 8 \mathrm{~h} \text { practical time in } \\
2 \text { weeks } \\
\text { (2) Control }\end{array}$ & $\begin{array}{l}30 \\
25\end{array}$ & 1 & 0 & $\begin{array}{l}\text { After } 1 \text { month no change between } \\
\text { groups in composite back pain scores } \\
\text { (range } 0-5):(1) 0.85 \text { (2) } 0.99 \text { or in } \\
\text { composite fatigue scores(range } 0-5) \text { : } \\
\text { (1) } 1.62 \text { (2) } 1.99\end{array}$ \\
\hline
\end{tabular}

The type of education and the intensity of the classes varied considerably in the studies. The least intensive educational interventions consisted of training for one hour on body mechanics. ${ }^{14}{ }^{15}$ The most intensive educational intervention was a back school consisting of five sessions: ${ }^{19}$ the first four 90 minute sessions were given during a two week period, the fifth session after two months. Instructions on body mechanics and exercises for back and abdominal muscles were given, and the subjects were encouraged to exercise at home. The education programme investigated in the study of Versloot $e t a l^{11}$ was the only one not primarily focused on body mechanics, but on stress and coping strategies. This was probably due to the fact that the subjects of this study were bus drivers, which was the only study population without heavy lifting tasks.

As five out of the six studies (83\%) showed no effect of education in the reduction of incidence of back pain or absenteeism, there is limited evidence that education, or at least the education programmes investigated in the studies at issue, is not effective in the prevention of back pain (level 3).

\section{EXERCISE}

Table 5 lists the three RCTs on the effectiveness of exercise in the prevention of back pain that were located. ${ }^{19} 2324$

Exercise programmes consisted of exercises specifically for back muscles over a period of 13 months with a mean of six sessions of 20 minutes per month, ${ }^{23}$ callisthenics exercises for back and abdominal muscles for 40 minutes biweekly for three months, ${ }^{19}$ or weekly sessions of 35 minutes at work plus 30 minutes at home with general stretching, strengthening, and cardiovascular exercises for 18 months. ${ }^{24}$

All three RCTs reported a positive effect of exercise. But all three studies were of low methodological quality, indicating limited evidence for the effectiveness of exercise in the prevention of back pain in industry (level 3 ).

\section{STATISTICAL POOLING}

Of the five studies on lumbar supports, three reported insufficient data to calculate an effect size. ${ }^{1517}{ }^{18}$ Either the number of subjects in each intervention group or data on the outcome measurement were missing. The remaining two studies $^{1416}$ used different outcome measures; therefore, we did not calculate a combined effect size.

Of the six studies on education, the bus drivers in the study of Versloot et $a l^{1}$ represented a very different population from that of the other five studies with subjects performing manual lifting tasks. However, these five studies used various outcome measures (tired back at the end of the day, ${ }^{20}$ composite back pain scale, ${ }^{22}$ number of painful months, ${ }^{19}$ incidence of back injury, ${ }^{14}{ }^{15}$ which we did not consider to be sufficiently similar to justify statistical pooling. 


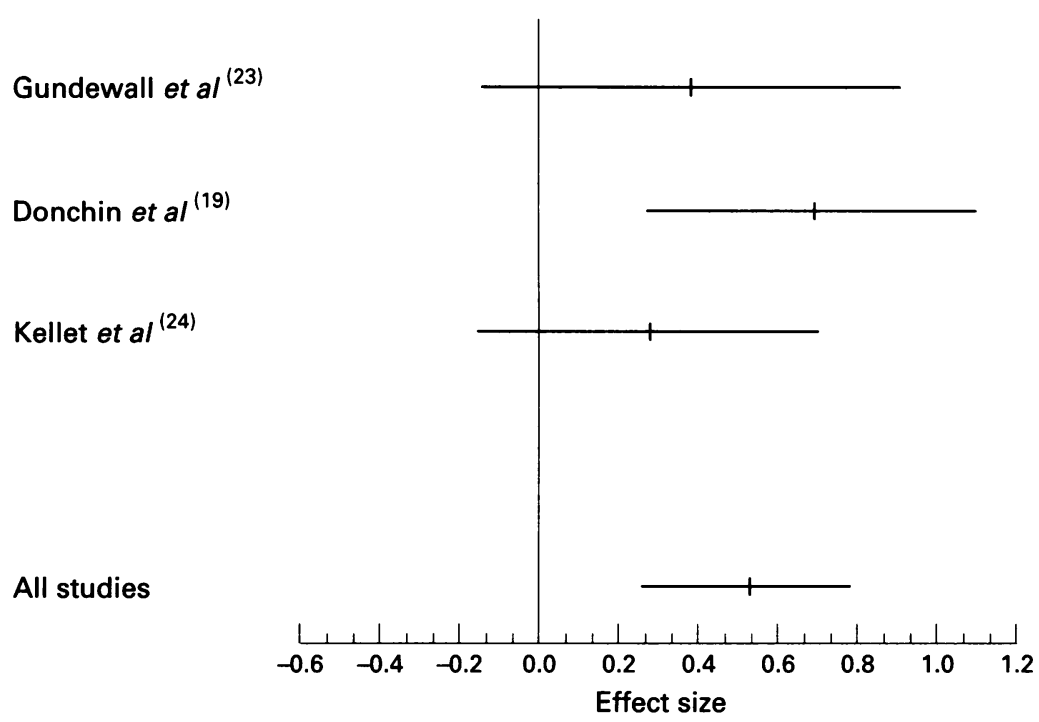

Effect sizes and 95\% confidence intervals for the studies separately and for the combined effect size of exercise on the incidence of back pain

The three studies on exercise all comprised subjects with heavy work. Although the interventions varied from trunk muscle exercises to cardiovascular exercises and the follow up period varied from 12 to 18 months, we considered the intensity of the training programmes and the duration of follow up to be sufficiently similar. Each study used a somewhat different outcome measure for back pain, but as all three outcome measures were self reported data on the incidence of back pain (number of days with back pain, number of painful months, and number of episodes with back pain, respectively), they were considered to be relatively similar. A homogeneity test for the effect sizes of the studies was performed, and homogeneity could not be rejected $(Q(2)=1.02 ; P>0.2)$. Therefore, the fixed effects model was used to combine the effect sizes of the studies. The figure shows the effect sizes for the incidence of back pain of each study separately and the combined effect size. The combined effect size of 0.53 (95\% CI 0.26 to 0.79 ) can be considered to be a medium sized effect. ${ }^{25}$ The combined effect size for the outcome measurement "sick leave due to back pain" was calculated similarly, but was based on two studies only, ${ }^{23}$ as the study of Donchin $e t a l^{19}$ did not report any data on sick leave. The combined effect size was 0.56 (95\% CI 0.22 to 0.90 ) for sick leave.

\section{Discussion}

Although the measures to prevent back pain described in this paper are widely used in industry, surprisingly little research has been carried out to evaluate the effectiveness of these interventions.

\section{LIMITATIONS OF THE REVIEW}

A potential limitation of our systematic review, and of most reviews in general, is the literature search. It is possible that we missed some published trials that used other keywords or had unclear abstracts. Furthermore, possibly not all studies will be indexed in the bibliographical databases we searched. As we limited our review to published studies, publication bias may have caused bias towards positive findings.

Although there is a lot of published material on the prevention of back pain in industry, we only selected 11 studies for our review. This is because most published papers did not evaluate the effectiveness of an intervention or, if they did, had a cross sectional or retrospective design, or lacked a control group. We have chosen to restrict our review to CCTs and have excluded studies with other designs, because studies without a concurrent control group are much more prone to bias. We therefore used the potentially most valid studies published.

Table 5 Controlled clinical trials on the effectiveness of exercise in the prevention of back pain in industry

\begin{tabular}{|c|c|c|c|c|c|c|c|c|}
\hline \multirow[b]{2}{*}{ Authors } & \multirow[b]{2}{*}{ Subjects } & \multirow[b]{2}{*}{ Interventions } & \multirow{2}{*}{$\begin{array}{l}\text { Subjects } \\
(n)\end{array}$} & \multirow{2}{*}{$\begin{array}{l}\text { Follow up } \\
\text { period } \\
\text { (months) }\end{array}$} & \multirow{2}{*}{$\begin{array}{l}\text { Validity } \\
\text { score }\end{array}$} & \multirow{2}{*}{$\begin{array}{l}\text { Main result (according to the } \\
\text { authors) }\end{array}$} & \multicolumn{2}{|c|}{ Effect size ${ }^{*}$} \\
\hline & & & & & & & Cohen's d & $95 \% C I$ \\
\hline $\begin{array}{l}\text { RCTs: } \\
\text { Gundewall et } a l^{3}\end{array}$ & $\begin{array}{l}\text { Hospital } \\
\text { workers }\end{array}$ & $\begin{array}{l}\text { (1) Exercises specific for back } \\
\text { muscle strength and endurance. } \\
6 \times 20 \text { min per month } \\
\text { (2) Control }\end{array}$ & 32 & 13 & 2 & $\begin{array}{l}\text { After } 13 \text { months decrease in } \\
\text { number of days with back } \\
\text { pain complaints in group } 1 \\
\text { (53.9) compared with group } \\
2 \text { (94.3) and in mean } \\
\text { number of days lost from } \\
\text { work: (1) } 1.0 \text { (2) } 4.84\end{array}$ & 0.38 & -0.14 to 0.91 \\
\hline Donchin $e t a l^{19}$ & $\begin{array}{l}\text { Hospital } \\
\text { workers }\end{array}$ & $\begin{array}{l}\text { (1) Calisthenic exercises for back } \\
\text { and abdominal muscles. } 45 \text { min } \\
\text { biweekly } \\
\text { (2) Instructions on body } \\
\text { mechanics and on exercises for } \\
\text { abdominal and back muscles. } \\
\text { Four sessions of } 90 \text { min in } 2 \\
\text { weeks plus fifth session after } 2 \\
\text { months } \\
\text { (3) Control }\end{array}$ & $\begin{array}{l}46 \\
46\end{array}$ & 12 & 2 & $\begin{array}{l}\text { Reduction in incidence of } \\
\text { low back pain episodes } \\
\text { (number of painful months) } \\
\text { after } 12 \text { months in group } 1 \\
\text { (4.5) compared with group } 2 \\
\text { (7.3) or group } 3 \text { ( } 7.4 \text { ). No } \\
\text { difference in back pain } \\
\text { incidence between group } 2 \\
\text { and group } 3 \text {. }\end{array}$ & 0.69 & 0.27 to 1.11 \\
\hline Kellet $e t a l^{24}$ & $\begin{array}{l}\text { Managerial } \\
\text { and shop floor } \\
\text { workers }\end{array}$ & $\begin{array}{l}\text { (1) General stretching, } \\
\text { strengthening, and } \\
\text { cardiovascular exercises. } 35 \mathrm{~min} \\
\text { weekly plus } 30 \text { min weekly at } \\
\text { home } \\
\text { (2) Control }\end{array}$ & 53 & 18 & 1 & $\begin{array}{l}\text { After } 18 \text { months decrease in } \\
\text { number of episodes of back } \\
\text { pain in group } 1(0.27) \\
\text { compared with group } 2 \\
(0.52) \text { and in number of } \\
\text { sick leave days due to back } \\
\text { pain: (1) } 2.73 \text { (2) } 4.13\end{array}$ & 0.28 & -0.16 to 0.71 \\
\hline
\end{tabular}


There is no evidence-based consensus on which criteria should be used for asssessing the methodological quality of controlled trials at this moment. Although the criteria we used are based on an earlier study ${ }^{26}$ and have been used in most other available checklists, ${ }^{27}$ the criteria are, to some extent, arbitrarily chosen.

METHODOLOGICAL QUALITY

The quality of all the studies selected for this review turned out to be disappointingly low, according to our criteria. None of the studies scored positive on $50 \%$ or more of the items covering the internal validity. The low overall quality of published studies has been noted previously for trials of therapies for low back pain . 8-11 28 The outcome assessment was not blinded in any of the preventive studies. As it is impossible to blind the subjects for the interventions reviewed here, it is even more essential to have a blinded outcome assessment.

Also, more attention should be paid to reporting how the randomisation procedure was carried out. Only two of the seven articles on RCTs described how this was performed, ${ }^{14}{ }^{23}$ of which only one reported a procedure which really seemed to exclude bias. ${ }^{14}$ Most other RCTs just mentioned that the interventions were allocated randomly, which is not sufficient. It has been shown that trials with inadequate randomisation procedures or unclear description of the procedure yield larger estimates of effects than trials in which an adequate procedure is reported. ${ }^{29}$ Therefore, we considered unclear procedures or procedures not described to be inadequate and the study therefore possibly biased.

Another problem was the assessment of compliance. It was surprising that so little attention was paid to the measurement of compliance with the intervention at issue.

EFFICACY

We have assessed the evidence for efficacy of an intervention with a rating system which takes into account the number, the quality, and the outcome of the studies. We found no evidence for or against the efficacy of lumbar supports in the prevention of back pain, due to conflicting results of the available studies. This is in accordance with the conclusions of other reviews on lumbar supports. ${ }^{356}$ These also state that there is insufficient evidence to recommend the use of these devices in industry, due to limited research and conflicting results.

There was limited evidence that education, varying from instructions on lifting techniques to back schools, has no effect in the prevention of back pain. The subjects in the studies on this intervention were mostly warehouse or hospital workers. It is remarkable, therefore, that the only study on education with a positive result (according to the authors) was a study with bus drivers as the study population. ${ }^{21}$ It is possible that for a more sedentary type of work there could be some effect of education. Another explanation of this finding would be that the type of the education programme was a deter- minant for its effectiveness. The intervention in the study of Versloot et $a l^{11}$ focused on stress and coping strategies, whereas the education programmes in the other studies were primarily focused on body mechanics. In a review on back schools, Nordin et al found conflicting results on the effect in primary prevention of back pain. They concluded that the contradictory results could be due to variations in company support, social security system, employee involvement, outcome measurement, and study population. More research is needed to determine if education programmes of another type or with a higher intensity could be effective in the prevention of back pain. But at this moment, education on body mechanics for employees with manual lifting tasks or other heavy work does not seem to be effective in the prevention of back pain.

We found limited evidence for a positive effect of exercise. The results of the studies were homogeneous, but all three studies were of low quality. We estimated the combined effect size to be about half an SD (medium effect), for both the outcome measurements incidence of back pain and sick leave. In a previously published meta-analysis of six studies on training programmes in the prevention of back pain in industry ${ }^{30}$ an effect size of 0.24 (a small effect) was found. In the analysis effect sizes on both the outcomes incidence of back pain and sick leave were combined. That a smaller effect was found in their meta-analysis could be due to the fact that, besides trials on exercise, it also included trials on education or ergonomic counselling.

Lahad et $a l^{4}$ conducted a recent review on four preventive interventions: education, lumbar supports, exercise, and risk modification. They included 64 studies in their review, most of which were not controlled. They came more or less to the same conclusions as in our review-namely, that there was limited evidence to recommend exercise, but insufficient evidence to recommend lumbar supports or education to prevent low back pain in asymptomatic subjects.

\section{Conclusions}

Despite the widespread use of preventive measures in industry, only a few controlled trials have been conducted to evaluate the effectiveness of these interventions. The studies that have been conducted are, in general, of low methodological quality. It is therefore clear that more, and particularly, high quality research is needed to give more insight in the effectiveness of common preventive measures. The internal validity of studies can easily be much improved if more attention is given to the randomisation procedure and a description of it, blinding of outcome measurements, and assessment of compliance. At this moment, given the small amount of evaluative research available, there is limited evidence for the effectiveness of exercise, and limited evidence that education is not effective. There is no conclusive evidence for or against the effectiveness of lumbar supports in the prevention of back pain in industry. 


\section{Appendix}

$\mathrm{A}=$ Positive if the groups were similar for at least three of the following five items: age, back pain history, back pain at baseline, sick leave history, type and intensity of work.

$\mathrm{B}=$ Positive if the randomisation procedure was described and excluded bias - for example, use of random number table.

$\mathrm{C}=$ Positive if the loss to follow up was $<20 \%$. Loss to follow up is all randomised people minus the number of people at main moment of effect measurement for the main outcome measure, divided by all randomised people $\times 100$.

$\mathrm{D}=$ Positive if other interventions were avoided-for example, lifestyle advice, ergonomic changes, etc.

$\mathrm{E}=$ Positive if the compliance was measured in each group and was satisfactory.

$\mathrm{F}=$ Positive if at least three of the following four outcome measures were assessed by a blinded assessor: sick leave or lost work days, incidence of back pain episode, pain intensity due to back pain, duration of back pain episode.

$\mathrm{G}=$ With a loss to follow up $<10 \%$ : positive if all randomised people for the most important outcome measures and on the most important moments of effect measurement minus missing values were included in the analysis, irrespective of non-compliance and cointerventions. If the loss to follow up was $>10 \%$ : positive if an intention to treat analysis was performed plus an alternative analysis which accounts for missing values.

$\mathrm{H}=$ Positive if inclusion and exclusion criteria were described and if there was a restriction to a homogenous study population.

I=Positive if the intervention groups were compared with a concurrent control group, derived from the same setting as the intervention groups.

$\mathrm{J}=$ Positive if at least three of the following four outcome measures were used: sick leave or lost work days, incidence of back pain episode, pain intensity due to back pain, duration of back pain episode.

$\mathrm{K}=$ Positive if the follow up was over six months.

$\mathrm{L}=$ Positive if the number of subjects in the smallest group immediately after randomisation was $>50$.

$M=$ Positive if the dropouts were described per study group, including reason for dropout, or if there were no dropouts.

$\mathrm{N}=$ Positive if the interventions education, exercise, or lumbar support were explicitly described.

$\mathrm{O}=$ Positive if the frequencies of most important outcome measures on the most important moments of effect measurement were reported.
Continuous variables: mean or median with standard error or percentiles.

1 Andersson GBJ. The epidemiology of spinal disorders. In: Frymoyer JW, ed. The adult spine: principles and practice. New York: Raven Press, 1991:107-46.

2 Van Tulder MW, Koes BW, Bouter LM. A cost-of-illness study of back pain in the Netherlands. Pain 1995;62:233-40.

3 Barron BA, Feuerstein M. Industrial back belts and low back pain: mechanisms and outcomes. $\mathcal{f}$ Occup Rehabi 1994;4:125-39.

4 Lahad A, Malter AD, Berg AO, Deyo RA. The effectiveness of four interventions for the prevention of low back pain. fAMA 1994;272:1286-91.

5 Genaidy AM, Simmons RJ. Can back supports relieve the load on the lumbar spine for employees engaged in industrial operations? Ergonomics 1995;38:996-1010.

6 Minor SD. Use of back belts in occupational settings. Phys Ther 1996;76:403-8.

7 Nordin M, Cedraschi C, Balagué F, Roux EB. Back schools in prevention of chronicity. Baillières Clin Rheumatol 1992; 6:685-703.

8 Koes BW, van den Hoogen HMM. Efficacy of bed rest and orthoses of low back pain: a review of randomized controlled trials. European fournal of Physical Medicine and Rehabilitation 1994;4:86-93.

9 Koes BW, van Tulder MW, van der Windt DAWM, Bouter LM. The efficacy of back schools: a review of randomized clinical trials. F Clin Epidemiol 1994;47:851-62.

10 Koes BW, Bouter LM, Beckerman H, van der Heijden GJMG, Knipschild PG. Physiotherapy exercises and back GJMG, Knipschild PG. Physiotherapy exercises

11 Van Tulder MW, Koes BW, Bouter LM. Conservative treatment of acute low back pain: a systematic mega-review of 81 randomized clinical trials of 11 interventions. In: Van Tulder MW, Koes BW, Bouter LM, eds. Low back pain in primary care: effectiveness of diagnostic and therapeutic interventions. Amsterdam: EMGO-Institute, 1996:205-44.

12 Bigos SJ, Bowyer OR, Braen GR, Brown K, Deyo R, Haldeman $S$, et al. Acute low back problems in adults. Clinical practice guideline No 14. Rockville, MD: Agency for Health Care Policy and Research, Public Health Service, US Department of Health and Human Services; 1994 Dec. (AHCPR Publ No 95-0642.)

13 Cooper H, Hedges LV, eds. The handbook of research synthesis. New York: Russel Sage Foundation, 1994.

14 Walsh NE, Schwartz RK. The influence of prophylactic orthoses on abdominal strength and low back injury in the workplace. Am $₹$ Phys Med Rehabil 1990;69:245-50.

15 Reddell CR, Congleton J, Huchingson RD, Montgomery JF. An evaluation of a weightlifting belt and back injury prevention training class for airline baggage handlers. Applied Ergonomics 1992;23:319-29.

16 Alexander A, Woolley SM, Bisesi M, Schaub E. The effectiveness of back belts on occupational back injuries and worker perception. Professional Safety 1995;22-6.

17 Anderson CK, Morris TL, Vechin DC. The effectiveness of using a lumbar support belt. Dallas, Texas: Advanced using a lumbar

18 Thompson L, Pati AB, Davidson H, Hirsh D. Attitudes and back belts in the workplace. Work 1994;4:22-7.

19 Donchin M, Woolf O, Kaplan L, Floman Y. Secondary prevention of low-back pain: a clinical trial. Spine 1990;15: 1317-20.

20 Daltroy LH, Iversen MD, Larson MG, Ryan J, Zwerling C, Fossel AH, Liang MH. Teaching and social support: effects on knowledge, attitudes, and behaviours to prevent low back injuries in industry. Health Educ $O 1993 ; 20: 43-62$.

21 Versloot JM, Rozeman A, van Son AM, van Akkerveeken PF. The cost-effectiveness of a back school program in industry: a longitudinal controlled field study. Spine 1992; industry:

22 Feldstein A, Valanis B, Vollmer W, Stevens N, Overton C. The back injury prevention project pilot study: assessing the effectiveness of Back Attack, an injury prevention program among nurses, aides, and orderlies. $\mathcal{F}$ Occup Med 1993;35:114-20.

23 Gundewall B, Liljeqvist M, Hansson T. Primary prevention of back symptoms and absence from work: a prospective randomized study among hospital employees. Spine 1993; 18:587-94.

24 Kellet KM, Kellet DA, Nordholm LA. Effects of an exercise program on sick leave due to back pain. Phys Ther 1991;71: 283-93.

25 Cohen J. Statistical power analysis for the behavioral sciences. Revised ed. New York: Academic Press, 1977.

26 Chalmers TC, Smith H, Blackburn B, et al. A method for Chalmers TC, Smith $\mathbf{H}$, Blackburn B, et al. A method for Control Clin Trials 1981;2:31-49.

27 Moher D, Jadad AR, Nichol G, Penman M, Tugwell P Walsh S. Assessing the quality of randomized controlled trials: an annotated bibliography of scales and checklists. Control Clin Trials 1995;16:63-73.

28 Scheer SJ, Radack KL, O'Brien Jr DR. Randomized controlled trials in industrial low back pain relating to return to work. Part 1. Acute interventions. Arch Phys Med Rehabil 1995;76:966-73.

29 Schulz KF, Chalmers I, Hayes RJ, Altman DG. Empirical evidence of bias: dimensions of methodological quality associated with estimates of treatment effects in controlled trials. ҰAMA 1995;273:408-12.

30 Gebhardt WA. Effectiveness of training to prevent jobrelated back pain: a meta-analysis. Br $\mathcal{f}$ Clin Psychol 1994;33:571-4. 